DOI: https://doi.org/10.47405/mjssh.v6i7.878

\begin{tabular}{|c|c|}
\hline$y_{x=1}$ & Malaysian Journal of Social Sciences and Humanities (MJSSH) \\
\hline $\begin{array}{l}\text { Malaysian Journal of } \\
\text { Socrai scciecces and }\end{array}$ & Volume 6, Issue 7, July 2021 \\
\hline (MJ-SSH) & e-ISSN : 2504-8562 \\
\hline & $\begin{array}{l}\text { Journal home page: } \\
\text { www.msocialsciences.com }\end{array}$ \\
\hline
\end{tabular}

\title{
Hubungan antara Ketagihan Media Sosial dengan Pencapaian Akademik: Kajian di Fakulti Ekologi Manusia, Universiti Putra Malaysia (UPM)
}

\author{
Ida Nadiera Ngahdiman', Ratna Roshida Ab Razak ${ }^{1}$ \\ ${ }^{1}$ Jabatan Pengajian Kenegaraan dan Ketamadunan (JPKK), Fakulti Ekologi Manusia, \\ Universiti Putra Malaysia (UPM) \\ Correspondence: Ratna Roshida Ab Razak (ratna_razak@upm.edu.my)
}

\begin{abstract}
Abstrak
Kajian ini bertujuan untuk mengkaji hubungan antara ketagihan media sosial dan pencapaian akademik dalam kalangan pelajar tahun akhir Fakulti Ekologi Manusia di Universiti Putra Malaysia. Terdapat 125 orang pelajar tahun akhir yang terlibat dalam kajian ini. Pemilihan responden dilakukan melalui convenient sampling. Data dikumpul melalui edaran borang soal selidik. Social Media Addiction ScaleStudent Form telah digunakan untuk mengukur tahap ketagihan media sosial. Purata Nilai Gred Kumulatif (PNGK) digunakan untuk mengukur tahap pencapaian akademik pelajar. Hasil kajian menunjukkan media sosial yang sering digunakan oleh pelajar ialah aplikasi Whatsapp (84\%), Instagram (55.2\%) dan Youtube (44\%). Kebanyakan pelajar menghabiskan masa 5-6 jam (34\%) dalam satu hari untuk menggunakan media sosial. Selain itu, kebanyakan pelajar memperoleh PNGK 3.00 sehingga 3.45 (45.6\%). Dapatan kajian juga mendapati bahawa tidak terdapat hubungan yang signifikan antara tahap ketagihan media sosial dan tahap pencapaian akademik $(\mathrm{p}=0.696)$. Dapatan kajian ini telah menunjukkan bahawa ketagihan media sosial tidak memberi kesan negatif kepada pencapaian akademik pelajar. Sebaliknya ia menjadi 'pecutan momentum' kepada pelajar untuk lebih bersemangat dalam tempoh pembelajaran. Hal ini juga mungkin kerana penggunaan media sosial hari ini tidak terhad kepada hiburan semata-mata namun lebih daripada itu, seperti ruang untuk melakukan menjalankan perniagaan.
\end{abstract}

Kata kunci: media sosial, pencapaian akademik, ketagihan

\section{The Relationship between Social Media Addiction and Academic Achievement among Final Year Students of the Faculty of Human Ecology at Universiti Putra Malaysia (UPM)}

\begin{abstract}
This study aims to examine the relationship between social media addiction and academic achievement among final year students of the Faculty of Human Ecology at Universiti Putra Malaysia. There were 125 final year students involved in this study. Selection of respondents was done through convenient sampling. Data were collected through the distribution of questionnaires. Social Media Addiction Scale- Student Form was used to measure the level of social media addiction. Cumulative Grade Point Average (CGPA) is used to measure students' level of academic achievement. The results showed that the social media that are often used by students are Whatsapp applications (84\%), Instagram (55.2\%) and Youtube (44\%). Most students spend 5-6 hours (34\%) in a day using social media. In addition, most students obtained a CGPA of 3.00 to 3.45 (45.6\%). The findings of the study also found that there
\end{abstract}


was no significant relationship between the level of social media addiction and the level of academic achievement $(\mathrm{p}=0.696)$. The findings of this study have shown that social media addiction does not have a negative impact on students 'academic achievement. Instead it becomes an 'acceleration of momentum' for students to be more enthusiastic during the learning period. This is also possible because the use of social media today is not limited to entertainment alone but more than that, such as space to do business. Artikel dalam bahasa English perlu mempunyai tajuk dan abstrak dalam bahasa English

Keywords: social media addiction, academic achievement

\section{Pengenalan}

Dalam meniti arus kemodenan ini, kemajuan teknologi maklumat dan komunikasi (ICT) semakin pesat seiring dengan pembangunan masyarakat di serata dunia. Pembangunan dalam teknologi maklumat dan komunikasi yang meletakkan manusia kini berada dalam era Teknologi Industri 4.0, telah mempengaruhi gaya hidup masyarakat khususnya para pelajar kerana penggunaan telefon pintar kini menjadi semakin meluas. Kewujudan telefon pintar pada hari ini, yang merupakan kesan kemajuan teknologi maklumat seperti internet telah menggalakkan lagi penggunaan media sosial dalam kalangan pengguna yang mampu merentas sempadan dunia. Media sosial merupakan satu bentuk media elektronik yang membolehkan para pengguna menyertai, berkongsi dan mencipta maklumat melalui rangkaian sosial, blog, wikpedia, forum serta pelbagai ruang dan platform dalam dunia virtual dengan mudah (Norazlah \& Normaliza, 2017). Antara media sosial yang sering digunakan pada masa kini ialah Whatsapp, Twitter, Instagram, Facebook dan sebagainya.

\section{Sorotan Literatur}

Kajian lepas menunjukkan bahawa penggunaan media sosial dalam kalangan pelajar universiti memberi kesan positif dan negatif. Berdasarkan kajian yang dilaksanakan oleh Negussie dan Ketema (2014) di Punjab India, ternyata tiada perkaitan antara masa yang digunakan untuk melayari lama media sosial iaitu Facebook dengan keputusan GPA pelajar. Meskipun pelajar menggunakan media sosial, pelajar masih lagi dapat mengekalkan prestasi akademik mereka. Namun begitu, kajian daripada Heffner dan Tara (2016) yang dilaksanakan di Universiti Rowan, USA mengatakan bahawa sosial media juga turut memberi impak negatif kepada pencapaian akademik pelajar disebabkan berlaku penurunan GPA pelajar disebabkan kelemahan dalam menguruskan masa kerana masa banyak terbuang dengan melayari media sosial.

Berdasarkan akhbar Berita Harian yang bertarikh 3 Oktober 2016, UPM telah menjalankan sebuah kajian mengenai sindrom $4 \mathrm{~K}$ yang mempengaruhi kemerosotan akademik pelajar di UPM (Amin Ridzuan, Ahmad Suhael \& Zulkifli, 2016). Dalam kajian tersebut, ada berapa K yang diketengahkan. K yang pertama merujuk kepada kuliah iaitu pelajar tidak menumpukan perhatian dalam proses proses pengajaran dan pembelajaran di dalam kelas meskipun hadir ke kuliah. K yang kedua ialah katil yang membawa maksud pelajar tidur secara berlebihan. K seterusnya merujuk kepada kafeteria kerana pelajar membuang masa dan melepak di kafeteria dan $\mathrm{K}$ yang terakhir ialah komputer iaitu para pelajar menghabiskan waktu dengan media sosial dan permainan video, kafeteria dan komputer. Penggunaan media sosial termasuk dalam $\mathrm{K}$ yang merujuk kepada komputer iaitu pelajar menghabiskan masa dengan melayari media sosial sehingga mereka tidak dapat menumpukan perhatian yang sepenuhnya kepada pelajaran. Perkara tersebut memberi kesan kepada pencapaian akademik pelajar.

Media sosial banyak digunakan untuk membantu proses pengajaran dan pembelajaran (P\&P). Penggunaan media sosial dalam proses $\mathrm{P} \& \mathrm{P}$ adalah penting pada masa kini kerana seiring Pembelajaran Abad ke- 21 (PAP 21). Penggunaan media sosial dalam proses P\&P digunakan secara meluas di peringkat sekolah mahupun di peringkat institusi pengajian tinggi (IPT) bagi membolehkan para pendidik dan para pelajar meneroka pelbagai maklumat dan pengetahuan (Mohd. Noorhadi \& 
Zurinah, 2017). Segala maklumat boleh diperoleh hanya di hujung jari sahaja. Selain itu, media sosial juga turut memudahkan interaksi antara pendidik dan pelajar. Para pelajar dapat memperoleh maklumat terkini dan bertukar-tukar maklumat bersama rakan-rakan dan juga pendidik dengan pantas dan mudah (Mohd. Noorhadi \& Zurinah, 2017).

Walau bagaimanapun, media sosial juga turut memberi keburukan kepada kaedah pengajaran dan pembelajaran dalam sistem pendidikan sekiranya tidak digunakan dengan bijak. Pelajar yang banyak menghabiskan masa dengan media sosial menyebabkan mereka mengalami ketagihan untuk mengakses media sosial sepanjang masa (Che Su \& Nan Zakiah, 2014). Kelekaan dalam menggunakan media sosial menyebabkan para pelajar hilang fokus dan tidak dapat memberi tumpuan kepada pelajaran mereka. Kelekaan dan ketaasuban pelajar kepada media sosial boleh menyebabkan pencapaian akademik mereka merosot. Pencapaian akademik merupakan perkara penting bagi menentukan keupayaan menguasai sesuatu bidang ilmu. Ia juga penting untuk menentukan masa depan yang lebih baik (Mohadir, Rashidi \& Nashad, 2011). Oleh itu, sekiranya pelajar mempunyai pencapaian akademik yang tidak memberangsangkan, perkara tersebut memberi kesan kepada mereka pada masa hadapan kerana mereka perlu bersaing untuk memperoleh peluang pekerjaan.

\section{Metod Kajian}

Instrumen Social Media Addiction Scale- Student Form (SMAS-SF) yang diasaskan oleh Cengiz Sahin (2018) ini mengandungi 31 soalan. Instrumen ini mengandungi 4 sub-skala iaitu toleransi virtual, komunikasi secara virtual, masalah virtual dan maklumat virtual. Setiap sub-skala mempunyai jumlah soalan yang berbeza. Sub-skala pertama iaitu toleransi virtual mempunyai 5 soalan manakala sub-skala kedua, komunikasi secara virtual mempunyai 10 soalan. Untuk sub-skala ketiga iaitu masalah virtual mempunyai 9 soalan dan sub-skala keempat, maklumat virtual mempunyai 7 soalan. Soalan-soalan ini mengandungi 5 skala likert iaitu 1- Sangat tidak setuju, 2- Tidak setuju, 3- Neutral, 4- Setuju dan 5Sangat setuju. Data dianalisis menggunakan Statistical Package for Social Science (SPSS) software versi 21. Kajian ini menggunakan dua jenis analisis statistik iaitu statistik deskriptif dan statistik inferensi.

\section{Hasil Kajian}

\section{Demografi responden kajian}

Kebanyakan responden untuk kajian ini terdiri daripada pelajar perempuan $(86.4 \%)$ berbanding pelajar lelaki (13.6\%). Hal ini kerana kebanyakan pelajar tahun akhir Fakulti Ekologi Manusia terdiri daripada pelajar perempuan berbanding pelajar lelaki. Kebanyakan responden yang terlibat dalam kajian ini ialah berumur 20 sehingga 22 tahun iaitu seramai 78 orang (62.4\%). Kemudian, diikuti dengan pelajar dalam lingkungan umur 23 sehingga 25 tahun itu seramai 42 orang (33.6\%) manakala pelajar yang berumur antara 26 sehingga 28 tahun ialah seramai 5 orang $(4.0 \%)$. Terdapat seramai 108 orang responden berbangsa Melayu (86.4\%), 2 orang responden berbangsa India (1.6\%), 13 orang responden berbangsa Cina (10.4\%) dan 2 orang responden Bumiputera Sarawak (1.6\%). Kesimpulannya, majoriti responden yang terlibat dalam kajian adalah berbangsa Melayu.

\section{Tahap ketagihan media sosial}

Berdasarkan sub-skala toleransi virtual, kebanyakan responden bersetuju dengan soalan pertama yang menyatakan diri mereka sangat bersemangat untuk melayari media sosial (52\%) dan juga soalan kedua iaitu mencari sambungan di mana-mana untuk melayari media sosial (50.4\%). Walau bagaimanapun, kebanyakan pelajar tidak bersetuju dengan soalan yang menyatakan kehidupan tanpa media sosial menjadikan hidup mereka tidak bermakna (43.2\%). 
Seterusnya, untuk sub-skala komunikasi secara virtual menunjukkan bahawa kebanyakan responden bersetuju dengan soalan ke-12 iaitu mereka ingin meluangkan masa dengan media sosial sewaktu mereka keseorangan (47.2\%). Selain itu, kebanyakan responden bersetuju dengan soalan ke-15 yang menyatakan bahawa mereka melayari media sosial untuk berkomunikasi dengan orang lain $(51.2 \%)$. Meskipun begitu, terdapat seramai 51 orang pelajar kurang bersetuju dengan soalan ke-7 iaitu mereka memilih persahabatan di media sosial berbanding persahabatan di kehidupan sebenar (40.8\%). Selanjutnya, untuk sub-skala masalah virtual, kebanyakan responden bersetuju dengan soalan ke-19 iaitu media sosial menggembirakan mereka (40.8\%). Di samping itu, kebanyakan responden bersetuju dengan soalan ke-23 iaitu penggunaan media sosial menyebabkan produktiviti mereka semakin berkurangan (37.6\%).

Walau bagaimanapun, kebanyakan responden tidak bersetuju dengan soalan ke-17 yang menyatakan bahawa mereka berasa kesal apabila mengurangkan penggunaan media sosial (47.6\%). Selain itu, seramai 58 orang responden sangat tidak setuju dengan soalan ke-20 yang menyatakan bahawa penggunaan media sosial yang begitu kerap menimbulkan konflik dengan ahli keluarga mereka (46.4\%). Akhir sekali, sub-skala maklumat virtual menunjukkan seramai 71 orang responden bersetuju dengan soalan ke-26 iaitu mereka gemar menggunakan media sosial untuk mendapat maklumat tentang apa yang berlaku di sekeliling mereka $(60 \%)$. Selain itu, seramai 71 orang responden bersetuju dengan soalan ke-27 iaitu mereka melayari media sosial untuk mendapatkan maklumat yang dikongsikan oleh kumpulan di media sosial (56.8\%). Di samping itu, seramai 65 orang responden bersetuju dengan soalan ke-29 yang menyatakan tentang penggunaan media sosial dengan begitu membantu mereka untuk mendapat makluman mengenai kursus pengajian mereka (52\%).

Kesimpulannya, majoriti pelajar gemar menggunakan media sosial untuk mendapatkan maklumat tentang apa yang berlaku di sekeliling mereka. Walau bagaimanapun, majoriti pelajar berpendapat bahawa meskipun mereka menggunakan media sosial dengan begitu kerap, perkara tersebut tidak mencetuskan konflik sama ada dengan diri mereka sendiri ataupun orang lain, seperti kawan-kawan atau ahli keluarga mereka.

Berhubung dengan tahap ketagihan media sosial, hal ini boleh dikategorikan kepada empat tahap mengikut jumlah skala ketagihan media sosial iaitu 1- Rendah (31-61), 2- Sederhana (62-92), 3- Tinggi (93-123) dan 4- Sangat Tinggi (124-155). Berdasarkan dapatan, 2 daripada 125 orang responden (1.6\%) berada pada tahap pertama, iaitu tahap rendah. Untuk tahap ke-2 (sederhana) pula, terdapat seramai 47 orang responden (37.6\%) manakala bagi tahap ke- 3 (tinggi) pula ialah seramai 66 orang responden $(52.8 \%)$. Selebihnya, iaitu 10 orang responden $(8.0 \%)$ berada pada tahap ke- 4 (sangat tinggi). Nilai min, median dan mod $(2.672,3.00,3.00)$ menunjukkan kebanyakan pelajar berada pada tahap ketagihan media sosial yang ke-3 iaitu tahap tinggi. Kesimpulannya, berdasarkan nilai kekerapan, peratusan, min, median dan mod tersebut, kebanyakan pelajar berada pada tahap ketagihan media sosial yang ke-3 iaitu tahap tinggi.

\section{Jenis media sosial yang sering digunakan}

Rajah 1 menunjukkan jenis media sosial yang digunakan oleh responden. Berdasarkan jadual tersebut, seramai 105 orang responden sangat kerap (84\%). menggunakan aplikasi Whatsapp. Diikuti seramai 42 orang responden menggunakan aplikasi Facebook (33.6\%). Selain itu, penggunaan aplikasi Instagram dalam kalangan responden juga sangat kerap iaitu seramai 69 orang responden. (55.2\%). Seterusnya, seramai 57 orang responden tidak pernah menggunakan aplikasi Snapchat (45.6\%). Disamping itu, kebanyakan responden kerap (52 orang, $41.6 \%$ ) dan sangat kerap menggunakan Youtube (55 orang. 44\%). Selanjutnya, seramai 56 oarng responden tidak pernah menggunakannya aplikasi We Chat (44.8\%) manakala terdapat 54 orang responden pernah menggunakan aplikasi We Chat (43.2\%).

Kesimpulannya, antara media sosial yang sering digunakan oleh pelajar ialah aplikasi Whatsapp, (84\%). Instagram (55.2\%). dan Youtube,44\%). manakala aplikasi Facebook(33.6\%). hanya kerap digunakan oleh pelajar pada waktu-waktu tertentu. Di samping itu, kebanyakan pelajar tidak pernah menggunakan aplikasi Twitter, Snapchat dan We Chat. 


\section{Rajah 1: Jenis Media Sosial yang Sering Digunakan}

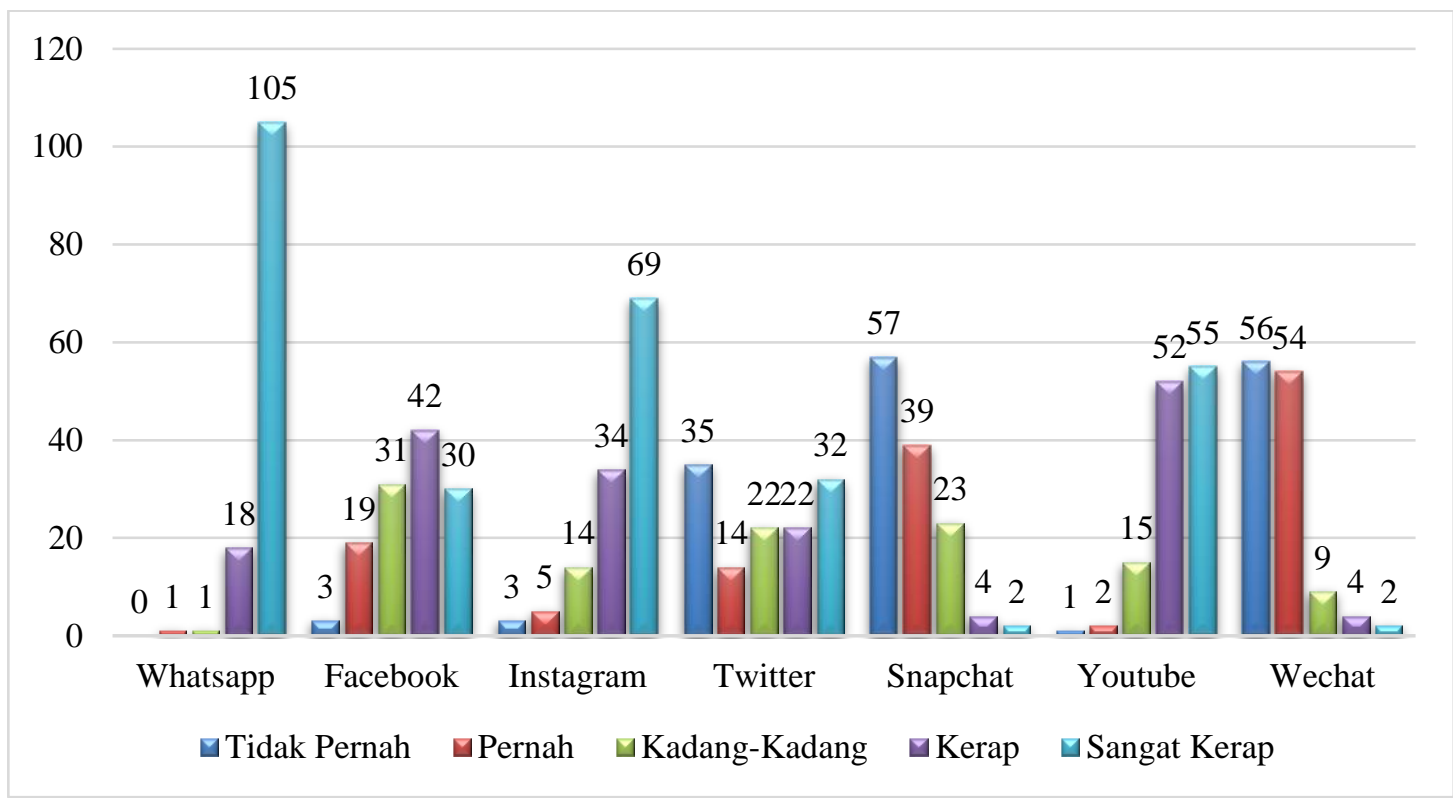

Rajah 2 menunjukkan kekerapan, peratusan, min, median dan mod tempoh masa penggunaan media sosial yang diperuntukkan oleh responden dalam masa satu hari. Terdapat satu $(0.8 \%)$ daripada 125 orang responden memperuntukkan kurang 1 jam dalam satu hari. Kemudian, seramai 9 orang responden $(7.2 \%)$ memperuntukkan masa antara 1 sehingga 2 jam dalam satu hari. Terdapat 40 orang responden (32\%) yang menggunakan media sosial antara 3 sehingga 4 jam. Seramai 42 orang responden (33.6\%) memperuntukkan masa antara 5 sehingga 6 jam dalam satu hari manakala selebihnya iaitu seramai 33 orang responden $(26.4 \%)$ memperuntukkan masa penggunaan media sosial lebih 6 jam dalam satu hari.

\section{Rajah 2: Masa Penggunaan Media Sosial dalam Satu Hari}

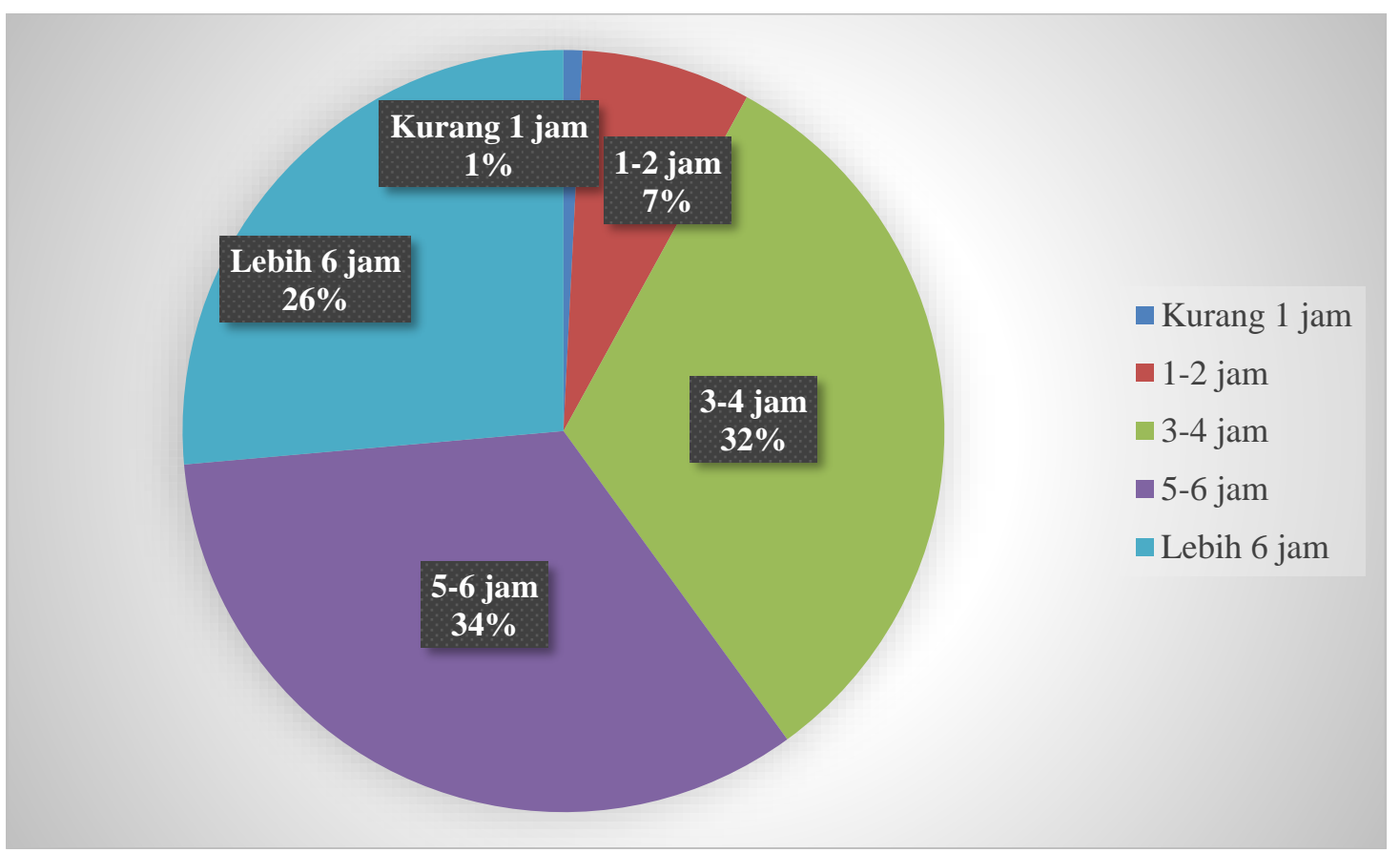

Keputusan ini menunjukkan bahawa kebanyakan pelajar memperuntukkan masa untuk penggunaan media sosial antara 5 sehingga 6 jam. Min, median dan mod di rajah tersebut $(3.78,4.00,4.00)$ 
menunjukkan majoriti pelajar menggunakan media sosial dalam tempoh antara 5 sehingga 6 jam. Berdasarkan hasil kajian, kebanyakan pelajar menghabiskan masa antara 5 sehingga 6 jam sehari untuk menggunakan media sosial. Kadar penggunaan media sosial melebihi lima jam dianggap sebagai ketagihan media sosial sepertimana kajian yang telah dijalankan oleh Kajian Institut Penyelidikan Pembangunan Belia Malaysia (IYRES) dan Universiti Utara Malaysia (UUM) di mana majoriti belia iaitu lebih 60 peratus daripada 2,007 orang responden yang berumur lingkungan 18 sehingga 25 tahun ketagih dengan internet iaitu salah satunya melalui penggunaan media sosial yang dikesan mampu menghabiskan masa lebih lima jam sehari, untuk melayari internet, terutama bahan berunsur hiburan (Rashiqah, 2016).

Kesimpulannya, tempoh masa penggunaan media sosial dalam kalangan pelajar amatlah membimbangkan. Kajian ini selari dengan dengan kajian ketagihan aplikasi Instagram dalam kalangan belia Malaysia oleh Nurzihan, Muhammad Hasrul dan Mohamad (n.d.) di mana majoriti daripada responden ialah pengguna tegar Instagram yang meluangkan masa sebanyak 4 jam sehingga 6 jam (57\%) manakala seramai 9\% daripada responden meluangkan masa lebih 6 jam dalam sehari. Keadaan ini menunjukkan kebanyakan pelajar menghabiskan masa antara 4 sehingga 6 jam dalam satu hari.

\section{Tahap pencapaian akademik}

Rajah 3 menunjukkan kekerapan dan peratusan tahap pencapaian akademik responden. Berdasarkan jadual di atas, responden yang memperoleh Purata Nilai Gred Kumulatif (PNGK) antara 3.00 sehingga 3.49 ialah seramai 57 orang (45.6\%), dan diikuti dengan PNGK antara 3.50 sehingga 3.74 ialah seramai 45 orang $(36.0 \%)$. Responden yang memperoleh PNGK antara 3.75 sehingga 4.00 ialah seramai 19 orang $(15.2 \%)$ manakala responden yang memperoleh PNGK antara 2.00 sehingga 2.99 ialah seramai 4 orang $(3.2 \%)$. Kesimpulannya, kebanyakan pelajar memperoleh PNGK antara 3.00 sehingga 3.49 .

Rajah 3: Tahap Pencapaian Akademik Responden

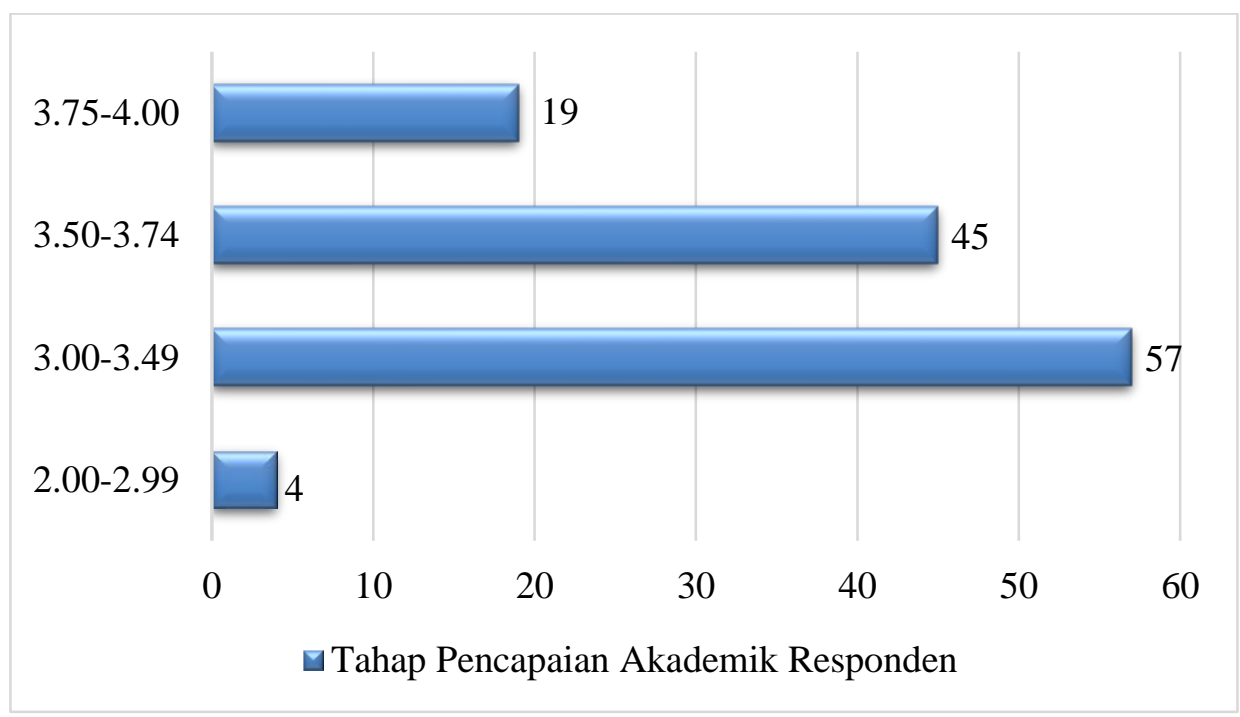

\section{Hubungan Ketagihan Media Sosial dengan Pencapaian Akademik}

Jadual 1 menunjukkan analisis khi kuasa dua antara kategori ketagihan media sosial dan kategori pencapaian akademik manakala Jadual 5 menunjukkan keputusan ujian khi kuasa dua. Berdasarkan analisis ujian Khi Kuasa Dua (Pearson Chi-Square) untuk sampel kajian ini, nilai p bagi ujian Khi Kuasa Dua Pearson iaitu 0.696, iaitu p> 0.05 menunjukkan bahawa tidak terdapat perbezaan yang signifikan antara tahap ketagihan media sosial dan tahap pencapaian akademik. Kesimpulannya, ketagihan media sosial tidak mempengaruhi pencapaian akademik kerana tiada hubungan yang signifikan antara tahap ketagihan media sosial dan tahap pencapaian akademik. 
DOI: https://doi.org/10.47405/mjssh.v6i7.878

Jadual 1: Jadual Analisis Khi Kuasa Dua Kategori Ketagihan Media Sosial dan Kategori Pencapaian Akademik

\begin{tabular}{llllll}
\hline \multirow{2}{*}{$\begin{array}{l}\text { Kategori Ketagihan } \\
\text { Media Sosial }\end{array}$} & \multicolumn{2}{l}{ Pencapaian Akademik } & \multirow{2}{*}{ Jumlah } \\
\cline { 2 - 5 } & $\mathbf{2 . 0 0 - 2 . 9 9}$ & $\mathbf{3 . 0 0 - 3 . 4 9}$ & $\mathbf{3 . 5 0 - 3 . 7 4}$ & $\mathbf{3 . 7 5 - 4 . 0 0}$ & \\
\hline 1 (Rendah) & 0 & 1 & 1 & 0 & 2 \\
2 (Sederhana) & 1 & 22 & 16 & 8 & 47 \\
3 (Tinggi) & 2 & 27 & 26 & 11 & 66 \\
4 (Sangat Tinggi) & 1 & 7 & 2 & 0 & 10 \\
Jumlah & 4 & 57 & 45 & 19 & $\mathbf{1 2 5}$ \\
\hline
\end{tabular}

Jadual 2: Ujian Khi Kuasa Dua

\begin{tabular}{lcccc}
\hline & Nilai & df & Asymp. Sig. (2-sided) \\
\hline Pearson Chi-Square & $6.433^{\text {a }}$ & 9 & .696 \\
\hline
\end{tabular}

\section{Perbincangan Kajian}

Kajian ini dijalankan bagi mengkaji hubungan ketagihan media sosial dan pencapaian akademik dalam kalangan pelajar. Dapatan menunjukkan bahawa aplikasi media sosial yang sering digunakan oleh pelajar ialah Whatsapp (84\%), Instagram (69\%) dan Youtube (44\%). Meskipun Digital Report 2018 mengatakan aplikasi Facebook merupakan aplikasi yang paling aktif digunakan di Malaysia, namun dapatan kajian ini menunjukkan pelajar lebih aktif menggunakan aplikasi Whatsapp berbanding aplikasi Facebook. Selain itu, kajian mendapati pelajar memperuntukkan masa penggunaan media sosial 5 hingga 6 jam dalam satu hari. Kadar penggunaan media sosial melebihi lima jam dianggap sebagai ketagihan media sosial sepertimana kajian yang telah dijalankan oleh Kajian Institut Penyelidikan Pembangunan Belia Malaysia (IYRES) dan Universiti Utara Malaysia (UUM) di mana majoriti belia iaitu lebih 60 peratus daripada 2,007 orang responden yang berumur lingkungan 18 sehingga 25 tahun ketagih dengan internet iaitu salah satunya media sosial kerana dikesan menghabiskan masa lebih lima jam sehari, untuk melayari internet, terutama bahan berunsur hiburan (Rashiqah, 2016). Perkara ini agak membimbangkan kerana perkara tersebut boleh menjejaskan rutin harian pelajar kerana menghabiskan masa terlalu lama dengan media sosial (Allya et al., 2014).

Dalam hal ini, ketagihan media sosial tidak mempengaruhi pencapaian akademik kerana tiada perbezaan yang signifikan antara tahap ketagihan media sosial dan tahap pencapaian akademik. Kajian ini disokong oleh dapatan kajian yang dilakukan oleh Negussie dan Ketema (2014) di Punjab, India mendapati bahawa tiada perkaitan antara masa yang digunakan untuk melayari lama media sosial iaitu Facebook dengan keputusan Gred Purata Pelajar (GPA) pelajar kerana para pelajar masih lagi dapat mengekalkan prestasi akademik mereka di samping mereka juga mengakses laman sosial. Dapatan kajian yang sama diperoleh oleh Othman, Apandi, \& Ngah, (2017) dalam kajian mereka mengenai kesan penggunaan media sosial terhadap prestasi akademik pelajar di Terengganu. Mereka mendapati tidak ada hubungan yang signifikan antara penggunaan media sosial dengan pencapaian akademik kerana faktor utama kemerosotan pencapaian akademik adalah berpunca daripada tingkah laku pelajar dan pengurusan masa yang kurang efisien. Dapatan yang sama juga diperoleh Ezeabii, Chibuike dan Udeh (2019) iaitu media sosial memberi pengaruh positif kepada para pelajar kerana ia menyediakan pelbagai sumber kepada para pelajar untuk meningkatkan pemahaman mereka, membantu pelajar untuk berinteraksi dengan rakan sebaya, memberikan maklumat yang relevan untuk kerja penyelidikan, membantu pelajar dalam melakukan tugasan kelas serta membantu pelajar untuk lebih mahir dengan penggunaan komputer atau peranti elektronik lain.

Oleh itu, ketagihan media sosial tidak menyebabkan pencapaian akademik pelajar tahun akhir merosot, namun sebaliknya ia menjadi 'momentum booster' kepada pelajar untuk lebih bersemangat ketika 
mengulangkaji pelajaran apabila keletihan dan mengantuk ketika menyiapkan tugasan atau mengulang kaji pelajaran.

\section{Kesimpulan}

Dapatan daripada kajian ini dengan jelas mendapati bahawa ketagihan media sosial tidak memberi kesan terhadap pencapaian akademik pelajar. Hal ini kerana ketagihan menggunakan media sosial ini mempunyai banyak sebab dan alasan dan bukanlah semata-mata untuk tujuan hiburan sahaja, malahan besar kemungkinan media sosial hari ini digunakan sebagai ruang untuk perniagaan. Dapatan kajian mengenai tahap ketagihan media sosial dalam kalangan pelajar boleh dikategorikan sebagai tinggi manakala masa penggunaan media sosial ialah antara 5 sehingga 6 jam dalam satu hari.

Walau bagaimana pun, kajian ini menunjukkan para pelajar masih lagi dapat mengekalkan prestasi akademik mereka dengan memperoleh PNGK yang baik dan cemerlang. Beberapa cadangan bagi tujuan penambahbaikan dari segi penggunaan media sosial dalam kalangan pelajar dan pencapaian akademik pelajar. Dalam hal ini, pensyarah juga memainkan peranan penting kerana keberkesanan sistem pendidikan negara ditentukan oleh guru kerana mereka bertindak sebagai agen pelaksana kurikulum (Norhana et al., 2016). Pensyarah dicadangkan supaya melaksanakan penambahbaikan dalam proses pengajaran dan pembelajaran $(\mathrm{P} \& \mathrm{P})$ dengan menjadikan media sosial sebagai Alat Bantu Mengajar (ABM). Noorhadi dan Zurinah (2017) menyatakan bahawa pengajaran dan pembelajaran (P\&P) dengan menggunakan media sosial dilihat sebagai perkara yang penting kerana selaras dengan perkembangan dunia pendidikan pada masa kini yang menekankan teknik Pembelajaran Abad 21. Tambahan lagi, hasil kajian mendapati bahawa kebanyakan para pelajar menghabiskan masa dengan melayari media sosial antara 5 sehingga 6 jam satu hari. Sebagai contoh, pensyarah boleh mencipta kumpulan yang disertai oleh pelajar-pelajar di media sosial seperti di laman Whatsapp dan Facebook. Melalui platform tersebut, pensyarah boleh berkongsi maklumat yang berilmiah serta menyediakan satu tugasan yang perlu dilaksanakan oleh pelajar di media sosial sama ada di ruangan komen atau pun di ruangan post. Oleh yang demikian, di samping melayari media sosial bagi tujuan hiburan, para pelajar dapat meningkatkan pengetahuan mereka serta dapat menggunakan media sosial dengan lebih bermanfaat.

Pensyarah juga perlu memantau serta memberi dorongan kepada pelajar agar menggunakan aplikasi media sosial dengan bijak dan mencadangkan agar pelajar mengikuti social media influencer yang berilmiah di aplikasi media sosial seperti Anthony Robind, Gary Wee, Dr Amalina Che Bakri, Ted Talks dan lain-lain supaya para pelajar dapat menambah ilmu pengetahuan melalui platform media sosial.

Meskipun dapatan ini menunjukkan bahawa tiada hubungan yang signifikan antara penggunaan media sosial dan pencapaian, namun ini bukanlah membawa erti bahawa pelajar boleh menggunakan media sosial mengikut cita rasanya. Pelajar perlu mengetahui keutamaan sebagai seorang pelajar. Pelajar perlu lebih bijak membahagikan masa untuk belajar, berhibur, bersukan dan sebagainya dengan seimbang. Selain itu, pelajar juga perlu tahu mengambil peluang melalui media sosial dengan cara menggunakannya secara kreatif dan kritis sebagai ruang untuk apa jua perkara yang boleh mendatangkan kebaikan kepadanya.

\section{Rujukan}

Ainin Sulaiman, M Muzamil Naqshbandi, Sedigheh Moghavvemi \& Noor Ismawati Jaafar. (2015). Facebook Usage, Socialization and Academic Performance. Computers \& Education, 83. 64-73.

Allya Cassandra Alim, Chan, A. H. Z., Ferlis Bahari., Chua, C. B., Jasmine Adela Mutang \& Lailawati Madlan. (2014). Fenomena Ketagihan Facebook dan Keengganan Berkomunikasi secara Bersemuka dalam kalangan Remaja. Retrif dari https://www.ums.edu.my/fpp/images/download/proseding_skik2014/Ally cassandra alim.pdf 
DOI: https://doi.org/10.47405/mjssh.v6i7.878

Berita Harian. (2018, Februari 8). Industri 4.0 Perlu Seiring Pembangunan Nilai Kemanusiaan Berita Harian. Retrif dari https://www.pressreader.com/malaysia/berita-harianmalaysia/20180208/281990377976727

Che Su Mustaffa \& Nan Zakiah Megat Ibrahim. (2014). Persepsi Dan Penggunaan Media Sosial Dari Perspektif Ibu Bapa: Satu Analisis Kualitatif. Malaysian Journal of Communication, 30, 43-74. Retrif dari http://journalarticle.ukm.my/8022/

Ezeabii, I. C., Chibuike, V. C., \& Udeh, S. O. (2019). Influence of Social Media on Academic Performance of Business Education Students of Public Universities in South-East States of Nigeria. British Journal of Education, 7(2), 81-90.

Heffner, T. (2015). The Effects of Social Media Use in Undergraduate Students (Disertasi Kedoktoran). Retrif dari https://rdw.rowan.edu/etd/1440/

Mohd Mohadir Harun, Mohd Rashidi Omar \& Ahmad Nashad Zakaria. (2018). Faktor yang Mempengaruhi Pencapaian Akademik Pelajar. Kementerian Pengajian Tinggi Malaysia. Retrif dari

https://www.researchgate.net/publication/327679092 Faktor Yang Mempengaruhi Pencapaian Akademik_Pelajar

Mohd. Noorhadi Mohd. Yusof \& Zurinah Tahir. (2017). Kepentingan Penggunaan Media Sosial Teknologi Maklumat Dalam Pendidikan Ipta. Journal of Social Sciences and Humanities, 12(3). Retrif dari http://ejournal.ukm.my/ebangi/article/viewFile/22483/7079

Nebiat, N. \& Girum, K. (2014). Relationship Between Facebook Practice and Academic Performance Of University Students. Asian Journal of Humanities and Social Sciences, 2(2).

Norashikin Abu Bakar, Ramli Basri \& Foo, S. F. (2015). Hubungan Kepimpinan Guru dengan Pencapaian Akademik Pelajar. International Journal of Education and Training (InjET), 1(2), 111.

Norazlah Mat Il \& Normaliza Abd Rahim. (2017) Tahap penggunaan instagram dalam kalangan pelajar Di Universiti Putra Malaysia. Journal of Business and Social Development, 5(2), 111 121.

Norhana Mohd Saad, Juliana Baharuddin \& Siti Noor Ismail. (2016). Hubungan Antara Tahap Kompetensi Fungsional Guru Dengan Pencapaian Akademik Pelajar di Sekolah Menengah di Negeri Kelantan. Proceeding of ICECRS, 1, 199-208, doi: https://doi.org/10.21070/picecrs.v1i1.602

Othman, W. W., Apandi, Z. F., \& Ngah, N. H. (2017). Impact of Social Media Usage on Students Academic Performance in Terengganu, Malaysia. Journal of Applied Environmental, 7(5), 140144.

Rashiqah Ilmi Abdul Rahim. (2016, Ogos 14). Majoriti Belia Negara Ketagih Internet, Media Sosial, Berdepan Risiko Masalah Mental. Berita Harian. Retrif dari https://www.bharian.com.my/node/182970

Sahin, C. (2018). Social Media Addiction - Student Form: The Reliability and Validity Study. The Turkish Online Journal of Educational Technology, 17(1). 